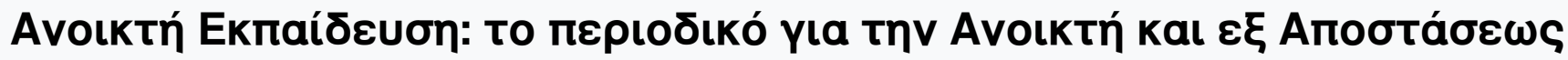

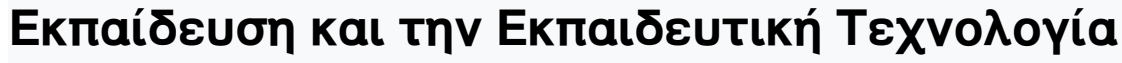

Tóp. 4, Ap. 1 (2008)

\section{Open Education}

The humal ik Open and Dthance Education and Educational Tequnctory

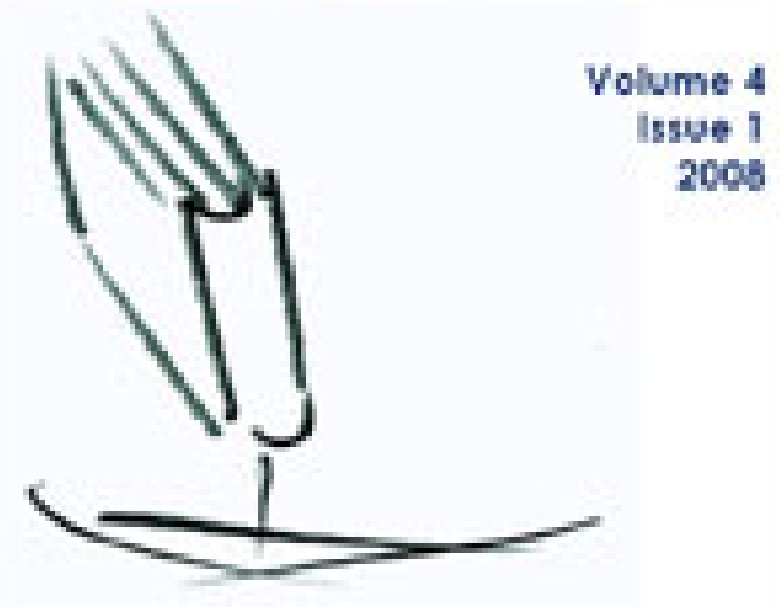

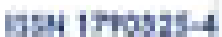

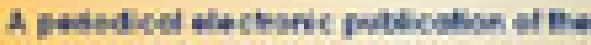

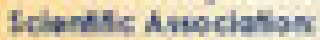

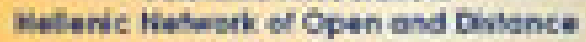
Id ecatiat
Factors Influencing the Completion of Dissertations by Students of Post-Graduate Diploma in Education (PGDE) by Distance Learning in Southwestern Nigeria

\section{Felix Kayode Olakulehin, Olugbenga David Ojo}

doi: $10.12681 /$ jode. 9722 


\title{
Factors Influencing the Completion of Dissertations by Students of Post-Graduate Diploma in Education (PGDE) by Distance Learning in South-western Nigeria
}

Felix Kayode Olakulehin

Centre for Continuing Education \& Workplace Training National Open University of Nigeria

Victoria Island, Lagos.

felixkayman@yahoo.co.uk

Olugbenga David Ojo (Ph.D)

Directorate of Examinations and Assessment National Open University of Nigeria

Victoria Island, Lagos.

gbenga_ojo2001@yahoo.com

\begin{abstract}
This paper reports the outcome of a primary quantitative investigation into the factors responsible for the completion or otherwise of dissertation reports by postgraduate distance learning students in Nigeria. The study set out to determine the reasons why many postgraduate distance learners fail to complete their dissertations after the course work. Using a structured questionnaire designed on a five-Point Likert-type scale, the researchers captured the opinions of some postgraduate distance learners about the factors affecting their completion of their research work. The analysis of the study was done using simple percentages and it was found that many of the respondents had difficulty with statistical analysis; some others had problems identifying suitable research topics and; supervisor problem, among others, constituted the major challenges facing many of the respondents. The study concluded with some recommendations on how the administration of research work or dissertation writing by distance learners can be improved.
\end{abstract}

Keywords: dissertation, statistical analysis; research, postgraduate distance learners Introduction

In all educational programmes, the submission of an original essay, commonly referred to as 'dissertation report' is an essential component of the requirements for the fulfillment of the award of a degree or diploma. Postgraduate dissertation courses are designed to be the equivalent of a 4-credit hour of taught course. In the preparation of dissertation reports, students are expected to identify a suitable research problem worthy of investigation from a chosen field. The choice of research area and formulation of a suitable problem are the most difficult tasks confronting postgraduate research students. This is due to the fact that the identified problem is expected to meet the tripartite conditionalities of a significance, originality and feasibility. In addition to these conditionalities, students writing dissertations are required to consider whatever problems they identify vis-à-vis individual competence and professional experience, and possible difficulties such as availability of data, financial constraints and limitations of time.

Postgraduate distance learners like many of their conventional counterparts are equally susceptible to these challenges. The Postgraduate Diploma in Education (PGDE) is a conversion course which is designed to equip those who did not have prior teacher training with the skills, knowledge and ability to become effective teachers or educational practitioners. Participants in the PGDE at a distance tend to possess common characteristics. Common characteristics in the sense that many of them are matured, they work in educational institutions or related fields, many of them have social 
responsibilities, such as family, religious and other engagements which are competing for their time and attention.

Many conventional institutions in Nigeria have offered the PGDE to different groups of students. Few institutions in Nigeria have also offered the PGDE at a distance. Institutions such as the Distance Learning Institute (DLI) of the University of Lagos; the Centre for Distance Learning at the University of Ibadan; the Centre for Distance Learning at the University of Abuja, the National Open University of Nigeria and the National Teachers' Institute (NTI), Kaduna. The National Open University of Nigeria has admitted students into its PGDE programme and its first set have just completed the seond semester examinations in march/April this year. The university has also admitted a second set of students who took the $1^{\text {st }}$ semester examination in March/April this year. This development is in keeping with the policy of the university to admit students on semester basis, rather than on the basis of academic session as it is common in higher education institutions in Nigeria.

The NTI is the first teacher training institution in Nigeria empowered to train teachers solely at a distance. Established in 1976 its mandate was originally to upgrade the skills and training of the under-qualified and unqualified teachers within the school system following the launching of the Universal primary Education system in 1977 (NTI, n.d). The need to introduce the PGDE was also informed by the directive of the Federal Government that all persons that would teach in the nation's educational institutions must be qualified teachers who have undergone some training or the other in the principles and practice of education and its ancillary fields.

Thus, holders of bachelors degree or higher national diploma from cognate disciplines were required to enroll for the PGDE in order $t$ strengthen their expertise in the principles and practice of the teaching profession. The programme requires participants to undertake courses in the core fields of educational practice. The courses offered includes: the foundations of education- historical, philosophical, psychological and sociological; Educational management; Curriculum Organization and development; Instructional design and development; Vocational, career and guidance counselling; Comparative education; Special Teaching Methods for Individual Subject; Tests, measurement and Evaluation; Educational research methods; Statistical and data analysis; Psychology of Learning ; Developmental Psychology; Teaching practice and; Project Work (Dissertation).

The submission of a dissertation report at the end of the one-year PGDE programme is an important component of the course. Participants are required to investigate a selected problem of their choice within the education system and discuss their experience with their supervisors in order to present a rich and informative report which contributes significantly to the existing body of knowledge in the field. Dissertations are expected to project three kinds of merit that all disciplines values, namely: conceptual innovation, methodological rigor and rich, substantive content (Przeworski \& Salomon, 1995). Postgraduate distance learners, like conventional students, while writing the dissertation are confronted with a number of challenges. However, the situation of the postgraduate distance learners is deemed as peculiar because they do not have access to all the materials - human and otherwise which their conventional counterparts have at their disposal. The isolation of distance learners makes it more difficult for them to interact with their peers/colleagues who may have useful 
tips/advice on how they can approach their research work. Thus it is usually a challenging task to complete postgraduate dissertation by distance learners. The use of library materials by students depended on the nature of subjects and the availability of relevant materials. Students are found to be making use of local library where it exists (Kate, Lorna \& Neil, 1997). The primary purpose of this study therefore is to investigate the factors that influence, positively and negatively, the preparation and completion of distance postgraduate dissertations and examine ways in which the supervision of distance postgraduate dissertations can be improved.

\section{Methodology}

\section{Population and Sampling}

The population for this study comprises of all registered students for the PGDE programme under the National Teachers' Institute, Kaduna. 220 students registered in 22 Centres of the Institute in six states of the southwestern region of Nigeria formed the sample for this study.

Instrumentation and Procedure of Administration

The instrument used consists of a two-page questionnaire divided into two sections. Section A relates to details about the personal data of the respondents while section $B$ sought opinions about the factors that influence completion of distance PGDE dissertation and the challenges confronting participants in the programme. The section sought responses to items contained on a five point Likert type scales of 'Strongly Agree' 'Agree' 'Undecided) 'Disagree' 'Strongly Disagree'. An open ended item sought to identify five major difficulties faced by students in the process of dissertation-writing. The instrument was validated by experts in educational research and statistics at the Directorate of Examinations and Evaluation of the national Open University of Nigeria. Ten questionnaires were sent to each of the identified study centres in each state and the centre coordinators were required to distribute to any ten students of their choice. The test-retest reliability of 0.05 was calculated.

\section{Results and Findings}

Only 170 questionnaires were returned to the researcher representing $77.3 \%$ of the response rate. Twenty questionnaires were discounted due to factors such as completion of two different responses to the same item, more than half of the items not responded to, extreme mutilation. Thus, only 150 questionnaires were finally accepted for processing. The sample contained 68 males and 82 females. All the respondents work in an educational institution or an education-related system. All respondents are married.

Frequency Tabulation of Responses of Postgraduate Distance Learners of NTI regarding the Factors Influencing their Completion of their Dissertations

\begin{tabular}{|c|c|c|c|c|c|c|}
\hline $\mathbf{S} / \mathbf{N}$ & Items & $\begin{array}{l}\text { Strongly } \\
\text { Agree }\end{array}$ & Agree & Undecided & Disagree & $\begin{array}{l}\text { Strongly } \\
\text { disagree }\end{array}$ \\
\hline 1 & $\begin{array}{ll}\text { I had no } & \text { problem } \\
\text { identifying a } & \text { research } \\
\text { topic } & \\
\end{array}$ & $15(10 \%)$ & $51(34 \%)$ & $8(5.3 \%)$ & $31(20.7 \%)$ & $45(30 \%)$ \\
\hline 2 & $\begin{array}{l}\text { My research topic } \\
\text { relates to my teaching } \\
\text { subject }\end{array}$ & $79(52.7 \%)$ & $38(25.3 \%)$ & - & $23(15.3 \%)$ & $20(13.3 \%)$ \\
\hline 3 & $\begin{array}{l}\text { I had no problem } \\
\text { getting }\end{array}$ & $12(8 \%)$ & $33(22 \%)$ & - & $69(46 \%)$ & $36(24 \%)$ \\
\hline
\end{tabular}




\begin{tabular}{|c|c|c|c|c|c|c|}
\hline & $\begin{array}{l}\text { resources/materials for } \\
\text { my research work }\end{array}$ & & & & & \\
\hline 4 & $\begin{array}{l}\text { My supervisor selected } \\
\text { a research topic for me }\end{array}$ & $44(29.33 \%)$ & $21(14 \%)$ & $16(10.67)$ & $\begin{array}{l}41 \\
(27.33 \%)\end{array}$ & $28(18.7 \%)$ \\
\hline 5 & $\begin{array}{l}\text { My supervisor } \\
\text { lives/works within my } \\
\text { geographic vicinity }\end{array}$ & $13(8.7 \%)$ & $8(5.3 \%)$ & $38(25.3)$ & $25(16.7 \%)$ & $66(44 \%)$ \\
\hline 6 & $\begin{array}{l}\text { I wish I could meet } \\
\text { with my supervisor } \\
\text { more often }\end{array}$ & $124(82.7 \%)$ & $26(17.3 \%)$ & - & - & - \\
\hline 7 & $\begin{array}{l}\text { The duration of the } \\
\text { research work is too } \\
\text { short }\end{array}$ & $39(26 \%)$ & $42(28 \%)$ & $24(15 \%)$ & $33(22 \%)$ & $12(8 \%)$ \\
\hline 8 & $\begin{array}{l}\text { It is difficult analyzing } \\
\text { the research work } \\
\text { without assistance } \\
\text { from my supervisor }\end{array}$ & $91(60.67 \%)$ & $27(18 \%)$ & - & $32(21.3 \%)$ & - \\
\hline 9 & 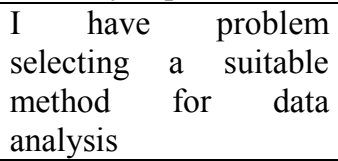 & $87(58 \%)$ & $9(6 \%)$ & $24(15 \%)$ & $\begin{array}{l}23 \\
(15.33 \%)\end{array}$ & $7(4.7 \%)$ \\
\hline 10 & $\begin{array}{ll}\text { I always } & \text { have } \\
\text { difficulty } & \text { with } \\
\text { statistical analysis } & \end{array}$ & $68(45.3 \%)$ & $54(36 \%)$ & $3(2 \%)$ & $21(14 \%)$ & $4(2.7 \%)$ \\
\hline 11 & $\begin{array}{l}\text { I prefer to use } \\
\text { computer-aided } \\
\text { analytical tools. }\end{array}$ & $16(10.7 \%)$ & $48(32 \%)$ & $13(8.7 \%)$ & $56(37.3 \%)$ & $27(18 \%)$ \\
\hline 12 & $\begin{array}{l}\text { I have problems } \\
\text { getting funds for my } \\
\text { research work }\end{array}$ & $38(25.3)$ & $40(26.7 \%)$ & - & $69(46 \%)$ & $3(2 \%)$ \\
\hline 13 & $\begin{array}{l}\text { My supervisor is not } \\
\text { interested in the topic I } \\
\text { wish to research on }\end{array}$ & $19(12.7 \%)$ & $5(3.3 \%)$ & $83(55.3 \%)$ & $794.7 \%)$ & $26(17.3 \%)$ \\
\hline
\end{tabular}

The study also provided an open ended item which required respondents to state in order of priority 5 major difficulties that have affected the preparation and completion of their dissertation reports. $37 \%$ of the respondents indicated that 'data analysis' is the most crucial factor that affected their completing the report; $28 \%$ opined that the 'time allocated' for the completion of the dissertation report was too short. $17 \%$ and 11 \%responded that 'funding' and 'lack of personal interest in research projects' respectively are the major influences that have affected their completion of their dissertation reports. $8 \%$ of the respondents claimed that 'the unavailability of the necessary and relevant research materials has been the factor that affected their completion of their dissertations. The remaining $4 \%$ of the respondents adduced the influencing factors against completion of their dissertations to issues such as: inability to see their supervisors, supervisors' apathy, poor training in research methods and statistical analysis, family problems, social commitments etc.

The result of the structured items in the questionnaire revealed that a total of 76 respondents representing $50.7 \%$ of the sample had no problem identifying their research topics. 117 respondents which make up $78 \%$ of the total sample population agreed that their research topic is related to their teaching subject and in some cases, their special subject during their bachelor's degree training. A major constraint is the sourcing of 
research materials which $70 \%$ of the respondents claim were difficult to get. $65 \%$ of the respondents reported that their supervisor indicated a research topic for them while another $69 \%$ replied negative to this item. For majority of the respondents the location of their supervisor is far apart from theirs, this being the view of $60.7 \%$ of the sample. Predictably, a large proportion of the sample population $(82.7 \%)$ wishes that they could meet more frequently with their supervisor. Their was a generally prevalent perception by $54 \%$ of the sample that the period slated for the research work needs to be extended while another $30 \%$ opined otherwise. Generally, $78.67 \%$ of the respondents found analysis of their research work difficult without assistance from their research supervisor, and consequently $64 \%$ had difficulty in selecting suitable method for data analysis. This may be due to the report to the item that $81.3 \%$ of the sample population always had difficulty with statistical analysis. When asked whether they had a preference for computer aided analytical tools, the response was ambivalent as $42.7 \%$ agreed while $45.3 \%$ disagreed. The response on whether respondents getting funds for the research work was also ambivalent as $60 \%$ agreed and the other $40 \%$ disagreed. It is was found that $55.3 \%$ of the respondents could not state whether or not their supervisor was interested in their research topic, while $22 \%$ disagreed and the rest agreed.

\section{Summary, Conclusions and Recommendations}

The results of this study have indicated that postgraduate research students in distance education generally experience difficulties in completing their research work (dissertation). While some had difficulty identifying research topics, many had no problem identifying suitable topics. This could be due to the fact that many of the topics identified by the respondents are related to their teaching subjects and in some cases their bachelors degree subject specialization. The results also showed that supervisors assisted their students in identifying research topics, probably to ensure that they are in the best position to assist them with research materials and statistical analysis of their research. A large proportion of the respondents wish to meet more frequently with their supervisors as in dictated in the study. Probably because of the difficulty in analyzing the statistical component of the research which the study showed that many students found very daunting. The ambivalence in the response on preference for computer aided analytical tools is essentially because the understanding of the application of computer aided statistical tools requires as much mental rigour as manual statistical analysis. What is apparent is that many students could not state whether or not their supervisors are interested in their research or they are just fulfilling teaching requirements.

These results have some major implications and recommendations for the practice of distance education. First, many postgraduate distance students face a lot of difficulty with statistical analysis of their research work and there is need to improve on the process of statistical instruction for them; supervisors of distance education students need to show greater enthusiasm to ensure that they assist their students to complete their dissertation reports without dropping out; Second, since may distance education students are parttime workers or people who have other social engagements, its is recommended that research project should be a session-long course to give the student ample opportunity to undertake the necessary studies for quality report-writing; Third, distance teaching institutions need to ensure that the contract with their instructional facilitators who supervise students' dissertations stipulates frequent meetings with the students, so as to enhance their preparation of the research work. 


\section{References}

Kate, S., Lorna, U., \& Neil, B. (1997) The use of libraries by Postgraduate distance learning students: a mismatch of expectations. Open Learning, 12(3), pp. 25- 33.

National Teachers Institute Nigeria (n.d.). /National Teachers Institute, Kaduna website. Teachers' Grade II Certificate by Distance Learning System (TC II by DLS). Recovered on $27^{\text {th }}$ March 2007 from: http://www.ntinigeria.org/tgpro.html

Przeworski, A \& Salomon, F. (1995) The Art of Writing Proposals: Some candid suggestions for Applicants to Social Science Research Council. SSRC: New York Recovered on $23^{\text {rd }}$ March 2007 from: www.ssrc.org 